\title{
Not Haitian: Exploring the Roots of Dominican Identity
}

\author{
Valerie Lamb ${ }^{1}$ and Lauren Dundes ${ }^{2, *}$ \\ 1 Department of Political Science, McDaniel College, 2 College Hill, Westminster, MD 21157, USA; \\ vml002@mcdaniel.edu \\ 2 Department of Sociology, McDaniel College, 2 College Hill, Westminster, MD 21157, USA \\ * Correspondence: ldundes@mcdaniel.edu
}

Received: 21 September 2017; Accepted: 27 October 2017; Published: 31 October 2017

\begin{abstract}
A literature review supplemented by interview data from a small sample of Haitian and Dominican immigrants living in Miami, Florida elucidates the complexities of Afrolatino-Dominican identity. The data include Dominican recollections of childhood warnings about threats posed by Haitians allegedly willing to cast spells and act as agents of punishment for misbehaving Dominican children. These data are consistent with antihaitianismo and the tendency for Dominicans to deny their African heritage in favor of their European Hispanic roots. The paper also explains how Dominicans' ethnic flexibility in navigating "racialized" social space in the US is relevant to future census measurement of race and ethnicity.
\end{abstract}

Keywords: Afrolatino; Dominicans; Haitians; race; racial identity; Census; antihaitianismo; Hispaniola; indio; colorism; immigrants

\section{Introduction}

Racism is commonly part of daily life for the estimated 150 million Afrolatinos-individuals of African descent living in Latin America and the Caribbean (Lennox and Minott 2011). Ninety percent (90\%) of Dominicans are Afrolatino, 1.5 million of whom live in the US, constituting the fifth-largest US Hispanic group (Brown and Patten 2013; López 2015). While one-quarter of US Hispanics are Afrolatino, the first nationally representative survey to measure this subgroup of US Hispanics was not implemented until 2014 (López and Gonzalez-Barrera 2016).

In this paper, we explore factors relevant to Dominican Afrolatino identity by examining academic literature surrounding the fraught relationship between Dominicans and Haitians, the legacy of colorism promulgated in colonial Dominican Republic, as well as interview data from seven former residents of Hispaniola (three Haitians and four Dominicans) now living in the US. We also provide historical and cultural background that elucidates Dominican racial identity both in the Dominican Republic and the US to complement our exploratory interview data that document continuing friction between Dominicans and Haitians, in part due to Dominican identity derived partly in contradistinction to Haitians.

\section{Essentialist versus Constructionist Models of Race}

Cultural factors that lead some to self-identify in a particular way, also referred to as situational identity, have been assessed using the Hispanic Origin Alternative Questionnaire Experiment focus groups (Compton et al. 2010, pp. 69-70). Acknowledgement that racial self-concept is a dynamic, negotiated status reveals a growing rejection of the Essentialist view of race as demarcating an already-constituted, coherent, socially or biologically homogeneous group (Barth 1969; Patten 2015). The contrasting Constructionist perspective of race as a fluid interplay of factors, including relativistic self-identification, provides an 
alternative point of view (Appiah 2015; Barth 1969; Roth 2012; Simmons 2008) relevant to understanding the role of Haitians in Dominicans' racial identity.

\section{The Demographic Rise and Conceptualization of Hispanics}

Between 1990 and 2013, the nation's Hispanic population grew faster than any other racial or ethnic group. The 54 million US Hispanics comprise 17\% of the US population and are projected to be $29 \%$ of the U.S. population by 2060 (Gonzalez-Barrera and López 2015). Dominicans are $0.6 \%$ of the US population, exceeded in Hispanic population only by Mexican Americans, stateside Puerto Ricans, Cuban Americans, and Salvadoran Americans (Brown and Patten 2013). The US Haitian population, 830,000 persons, is 0.3 percent of the total population, about half that of US Dominicans (Buchanan et al. 2010).

\section{A Brief History of Hispaniola}

The Dominican Republic and Haiti are two sovereign West Indies nations that share the island of Hispaniola in the Greater Antilles, the second largest island in the Caribbean after Cuba, and the location of Christopher Columbus' first European settlement in the Americas (1492-1493). Most of the native population, Arawak Taino, died due to exposure to new diseases. Between diseases and subsequent slavery of the remaining indigenous population, $95 \%$ of the original population was decimated (Gates 2011).

In 1503, the Spanish brought African slaves to the island. The French also established a colony on Hispaniola that became official in 1665. By 1697, the island was divided between Spain and France when Spain ceded the western third of the island to France. In Haiti, a successful rebellion by freed slaves in 1804 resulted in the world's first Black republic while the Dominican Republic became independent from Spain in 1821. The nature of Haiti's revolution resulted in a US arms and goods embargo, driven in part by US fears of their own slave rebellion. Haiti's financial woes were then exacerbated when France demanded high compensation for slaveholders deprived of their property.

Shortly after its 1821 independence from Spain in 1822, the Dominican Republic was subject to an oppressive twenty-two year occupation by a cash-strapped Haiti which mandated French instead of Spanish, the confiscation of all church land and property, and heavy taxes. After the Dominicans gained their independence from Haiti in 1844, tensions remained high as they thwarted various attempted Haitian invasions over the next 12 years (Mayes 2014; Wucker 1999).

Since the 1920s, when Haitians worked in the Dominican Republic's prosperous sugar industry, the Dominican Republic has made significant financial gains, in part due to employing Haitian migrants at low wages, as Haiti maintains a dubious distinction of being the poorest country in the western hemisphere. An extended multi-generational underclass of as many as a million Haitians living in the Dominican Republic is of indeterminate nationality, without the same rights and privileges as Dominicans, and subject to periodic expulsions and repatriation to Haiti where they no longer have connections or opportunities (Roth 2012).

The wide disparity in annual per capita income (US \$1300 in Haiti and US \$8200 in the Dominican Republic) continues to serve as an incentive for undocumented Haitians to seek work in the Dominican Republic, especially in the wake of the devastating 2010 Haitian earthquake that killed 100,000-160,000. Hurricane Matthew in October 2016 added to deficits in infrastructure and the need for humanitarian aid for hundreds of thousands of people (Ahmed 2016). Partly as a result of these kinds of events, Dominican resentment of Haitians has persisted (Dubois 2013). This raises questions about whether immigrants to the US from both countries have been able to distance themselves from these historically and culturally inculcated tensions. The answer lies largely in racial self-concept.

\section{Indios}

Because most Dominicans identify as indio, the dichotomous Black-White split shows the inadequacy of an oversimplified concept of race. The word indio (Indian in Spanish) denotes the Taíno-Arawak pre-Columbian inhabitants of Hispaniola. Ironically, this indigenous population that 
occupied Hispaniola, where Christopher Columbus (and his brother, Bartholomew) established the first European settlement in the Americas in 1492 and 1493, were victims of Spanish genocide (see the story of Anacaona for a poignant account of the egregious treatment of the indigenous population (Oliver 2009)). Among the more-than-a-dozen descriptors of skin color in the Dominican Republic (Duaney 2011; Guzmán 1974), indio is the term most commonly used, and a term that is employed only by Dominicans (Telles et al. 2015). Although most Dominicans (82\%) designate their race as indio while few (4\%) self-identify as Black, the indio population is phenotypically Black (Gates 2011) in sharp contrast to the historic one-drop rule in the US with its legacy of hypodescent.

The term indio belies that $73 \%$ of Dominicans are mulatto, $16 \%$ are White, $11 \%$ are Black (World Factbook 2016a). However, Dominicans are lighter-skinned than Haitians who have had much less miscegenation: 95\% are Black and 5\% are Mulatto and White (Simms et al. 2010; World Factbook 2016b). The term indio connotes Indian, and while their ancestry is as much as $9 \%$ Indian (Gates 2011), their African ancestry far surpasses their Indian ancestry and is determinative of their Black phenotype. Although Blacks and mulattoes comprise nearly $90 \%$ of the contemporary Dominican population, compared to other countries in the same hemisphere, they are uniquely indeterminate about their racial identity (Gates 2011).

There are a number of explanations for the term indio, including that indigeneity and Hispanicity serve to reinforce Dominican sovereignty given previous Haitian unification efforts and US imperialism (Candelario 2007). The weight of evidence, however, suggests that the term reveals Dominicans' denial of their blackness and acceptance of white primacy that includes calls to "adelantar la raza" or advance the race through only mixing with lighter-skinned people (Torres-Saillant 2000) while the term blanqueamiento connotes socioeconomic advancement through gaining acceptance from those classified and self-identified as White (Whitten and Torres 1998). The Dominican government promoted the belief that they have a non-Black population, reflected in its identity cards that classified $90 \%$ of the population as indio (Roth 2012). This manifestation of colorism, found in many parts of the world, is a legacy of colonialism that made race a traceable lineage and a legal status wherein whiteness was sought and blackness constituted regression (Jha 2016; Mayes 2014; Telles et al. 2015).

\section{How the Use of Indio Is Linked to Anti-Haitianismo}

Indio is a psycho-linguistic device that allows Dominicans to avoid using the terms negro and mulatto (which imply the presence of Black heritage). Black becomes indio oscuro while indio is a more neutral source of heritage, helping Dominicans maintain a Spanish identity. The term indio allows Dominicans to forget their African ancestors' enslavement while encouraging White Dominican oblivion about the legacy of slavery. Furthermore, the notion of the indio distances them from associations with being a "lowly Haitian or negro" (Suriel 2005, p. 28). "One of the most offensive things one could say to many other Afro-Caribbean immigrants, as well as to African immigrants, was to ask them if they were from Haiti" (Johnson 2016, p. 40).

Furthermore, "Dominican identity is constructed through a negative identification with the Haitian/negro identity" (Howard 2001, p. 3) as reflected in the frequent response to the question about what it means to be Dominican: "Not Haitian" (Gates 2011, p. 138). In fact, "Haiti stands for all that is allegedly not Dominican" (Howard 2001, p. 5). This is a view that is commonly expressed:

"Are Dominican people Black? Ask that to a Dominican person and you might get cursed out ... [A]cknowledgement of one's Blackness is perceived by many Dominican people as an irrational confession and sometimes an unforgivable betrayal, for to be Black in the Dominican Republic is to be the antithesis of Dominican national identity, to be anti-Dominican, in other words, to be an 'inferior' Black Haitian".

(Epsy 2015, para 7) 
Thus, antihaitianismo allowed Dominicans of color to bond and feel that, in spite of being second-class citizens in their own country and deemed subordinate to White people, their Spanish heritage placed them above intrinsically inferior Black people in Haiti (Sagás 2000).

\section{Skin Color}

Part of antihaitianismo is driven by Dominican awareness that their skin tone is lighter than their Haitian neighbors, reflected in the term cocolo that originated in the Dominican Republic. Often used disparagingly, it refers to non-Hispanic African descendants, or those with darker skin in general, especially Haitians (although Puerto Ricans also use the term to describe Dominican immigrants who appear Haitian) (Tuider and Caplan 2012). This slang term is just one manifestation of Dominicans' preference for identifying with their Spanish heritage over their African roots (Negrón 2014). In fact, in general, Dominicans only see Haitians as Black (Gates 2011) while rejecting their own African heritage. According to one report, some Dominicans with dark skin have explained it by past rapes purportedly committed by Haitians (Suriel 2005). Although some Dominicans are aware that their claims of Indo-Hispanic heritage are tenuous and that they rely on anti-Haitianismo and Negrophobia as identity boundary markers, they nevertheless form the basis of Dominican self-concept (Candelario 2007).

\section{Historical Roots of the Dominican-Haitian Division}

In order to see themselves as an ethnically and culturally Spanish nation, Dominicans discourage Haitian immigrants seeking better economic opportunities and condone the expulsion of Haitians, even those born and raised in the Dominican Republic (Amnesty International 2016). The simultaneous vilification of Haitians and glorification of Whites has been promulgated unambiguously by leaders at the highest levels including the reign of Rafael Trujillo (1930-1961) and Joaquín Balaguer, a proponent of antihaitianismo and Dominican president for much of the 1960s-1990s (Mayes 2014; Wucker 1999). Trujillo's genocide of Haitians in the Dominican Republic and darker complexioned Dominicans was sanctioned by members of the white elite (Candelario 2007; Sagás 2000).

The climate for acceptance of antihaitianismo is also undoubtedly lingering resentment of the 22 years of Haitian rule (1822-1844). In fact, Dominican Independence Day does not celebrate independence from Spain, but rather from Haiti (Suriel 2005), an unprecedented choice for this type of national commemoration. In contrast, Haitians embrace their victory over the French and revere their Black leaders, rather than Dominican heroes such as Christopher Columbus.

While in the US there are protests about Columbus Day, in the Dominican Republic, Columbus continues to be honored, part of hispanicismo, the celebration of the Dominican Republic's Spanish heritage (Mayes 2014). In a major tourist attraction in Parque Colon, a large bronze statue of Columbus erected in 1887 by French sculptor Ernest Guilbert in Columbus Plaza patently glorifies a white European (Krohn-Hansen 2001). The Columbus Lighthouse monument (Faro a Colón) that purportedly contains some of Columbus' hallowed remains was built recently (between 1986 and 1992) at a cost of $\$ 70$ million, revealing continued reverence for the Spanish and heroes who either possess or are portrayed as having Caucasian features (Gates 2011). In addition, their homage to Juan Pablo Duarte as a national hero is notable because even though he was only one of three men who orchestrated independence from Haiti, he also was three-quarters European with a white phenotype, evident in images of him with blue eyes, unlike the other founding fathers (Ramón Mella and Juan Sanchez Ramírez) who are revered less frequently (Eller 2016, 2017).

In contrast to Dominicans celebrating their connection to Columbus, Haitians pride themselves on their liberation from the French in the Haitian Revolution (1804), the only slave uprising that led to the founding of a state free from slavery and ruled by non-Whites and former captives. The heroes they celebrate are Black. By the end of April 1804, the white Haitians (of French descent) were practically eradicated, an event that created a permanent rift between the French and the Haitians. In addition, to counteract colorism that is perpetuated by distinguishing different people by their hue 
(Guzmán 1974), when Haitians defeated Napoleon and devised their own Constitution (1805), they decreed that Haitians would subsequently be known only generically as Blacks (Dubois 2013).

Despite tensions between Dominicans and Haitians, their joint history also includes collaboration that is often neglected by historians and scholars (see Paulino 2016). However, the extent to which their relations remain antagonistic and the potential impact of such sentiment in the United States are the focus of this paper.

\section{Methods}

After obtaining IRB approval, the first author interviewed a small sample of three Haitians and four Dominican first-generation immigrants from among clients at a Miami-area hair salon with primarily Haitian and Dominican customers (with permission of the Dominican salon owner). Given the propensity for "commercial friendships" and openness to sharing perspectives on various social issues in this type of setting (Garzaniti et al. 2011), the first author approached a select number of salon clients who had been talkative during previous salon visits. The exploratory nature of the work and the need to establish a rapport to elicit honest, thoughtful answers about a sensitive topic led to the decision to seek a small sample that might be willing to divulge sensitive information. All clients who were approached agreed to participate, at which time they completed an informed consent form and then moved to a room in the salon where the 20-30 min interview could be private.

The first author grew up with a white father and Dominican mother who identifies as indio and is among the almost half of all the Dominican Americans that immigrated since the 1990s (López 2015). Miami is one of the areas in the US known for having a significant Dominican diaspora community (besides the New York City metropolitan region, which alone is home to about $40 \%$ of Dominican Americans) (López 2015). Raised in a diverse neighborhood with close connections to Jamaicans, Ecuadorians, Cubans, Hondurans, Colombians, Indians, and Panamanians, the first author has a high comfort level with a culturally diverse array of people.

While one interviewee had been in the United States only for three years, the remainder had lived in the United States for at least 10 years. All but one interviewee spoke English. The only male interviewed, a Dominican, spoke Spanish throughout the interview. The other Dominicans spoke English, but inserted Spanish words when they felt unable to find an English equivalent during the interview.

Interviewees' ages ranged from 21 to 60 although most interviewees were around 45-55 years old. They were from a variety of social classes, including lower, middle, and upper middle classes. Despite the sensitivity of the topic, the interviewees expressed their confidence and trust in the first author after learning of her goal to better understand how racial identity relates to intercultural connections within the Afro-Caribbean diaspora. The scripted interview questions were as follows: What are your perceptions of (Haitians/Dominicans)? What is something from your childhood that you remember being told about (Dominicans/Haitians)? What images about (Dominicans/Haitians) do you recall from your early years? How has your self-image or identity changed since moving to America? How would you react if the island of Hispaniola were combined? What race do you consider yourself now versus before? Do you feel like you are more judged by your race in the US or your country of origin? Why?

\subsection{Interview Results}

\subsubsection{General Perceptions}

Interview data were organized by themes, including general perceptions of the other group (Haitians or Dominicans). Haitians emphasized the two countries' cultural similarities (e.g., their love of dancing, elaborate parties, the Carnival celebration) and food like plantains, rice and beans (irrespective of culinary distinctions based on French versus Spanish influences). Haitians also brought up musical similarities (meringue for Dominicans and konpa in Haiti) that are both based 
on European contradance and a five-beat African rhythm (Wucker 1999). In addition, they mentioned commonality as descendants of African slaves. They also acknowledged that Haiti is further behind in its economic welfare than the Dominican Republic. There was less variety in responses from Dominicans about Haitians; the most common Dominican impressions of Haitians were about their shouldering a disproportionate amount of the hard work in the Dominican Republic and their lower educational attainment compared to Dominicans.

\subsubsection{Childhood Warnings}

Interviewees were asked what they had learned about Dominicans/Haitians in childhood. Haitian answers included warnings about Dominicans treating Haitians like slaves. One interviewee had been told that Dominican women in Haiti worked as prostitutes (a depiction that Howard (2001) attributes to the comparatively large number of Dominican-managed brothels and beauty shops in Port-Au-Prince).

Dominicans were encouraged to be fearful of Haitians, likely part of anti-haitianismo. These apprehensions were instilled by references to Haitians as threatening, for example, by adults saying to children, "The demons are coming", when they passed a Haitian in the street. Some respondents' relatives also told them that Haitians would come after them if they misbehaved. Even looking at Haitians was ill-advised, as Dominican babies that looked into the eyes of Haitians supposedly risked being cursed as victims of the "evil eye". Other warnings included Haitians' purported ability to turn people who looked at them into a donkey or a tree, admonitions that could stem from Dominican uneasiness with Haitian vodou.

\subsubsection{New Self-Concepts as Immigrants}

When respondents were asked if their self-perceptions had changed since immigrating, both Haitians and Dominicans downplayed any changes and instead discussed their improved life chances due to opportunities available in the US. Haitians decried the lack of middle class in Haiti, and expressed pride in their achievement of middle class status in the US. One Haitian described how African American students had bullied her in middle and high school, deriding her accent and Haitian origins, taunts that were reportedly commonly directed at other Haitians as well. She said that over time, this mistreatment instilled greater pride in her background and spurred her to be more vocal in representing her country. Dominicans, like Haitians, seemed relatively unconcerned about assimilation or how they were perceived, focusing instead on their upward mobility.

\subsubsection{Lasting Impressions of Dominicans/Haitians}

When asked about whether images of the other culture (Dominicans/Haitians) that had been learned earlier in their lives had continued to resonate, Haitians said they only remembered what they had heard since they had not been exposed to Dominicans. They mentioned Dominicans' flair for doing hair and delicious food. One of the interviewees who grew up in the countryside far from the border of the Dominican Republic said she never heard anything about Dominicans.

In stark contrast to these responses, the Dominicans recalled very negative portrayals of Haitians. These centered around Haitian aggressiveness and dishonesty, as well as rumors of vodou which they viewed as an aberrant religion, consistent with historical scapegoating of the religion by colonial powers (Hebblethwaite 2015). One interviewee remembered knowing one good Haitian at her school, but felt the rest were very confrontational. She also recalled buying something from a convenience store and not receiving any of the expected change back from a Haitian cashier.

\subsubsection{Question of Reunification of Hispaniola}

When asked about how they would react if the Dominican Republic and Haiti became a single country on the island of Hispaniola, Haitians were much more positive than Dominicans. They believed that combining the countries would provide more funding and opportunity for both countries, saying 
it was an appealing prospect but one that would face resistance given the many differences and disagreements between the two countries. In contrast, Dominicans expressed uncertainty about the impact of such a union, and lacked any optimism about unification, given what they saw as irreconcilable cultural differences.

\subsubsection{Racial Self-Concept}

The first Haitian interviewee considered herself to be Black and a Haitian-American. The second Haitian interviewee did not identify as African American but instead only as Haitian, adding that she would "live and die" being Haitian. The third Haitian interviewee had always seen herself as $100 \%$ Haitian, and expressed her commitment to this identity, irrespective of her move to the US. She was saddened by people who were of Dominican descent, but who had been born and raised in Haiti, and pretended to be only Dominican, taking no pride in, and in fact rejecting, any connection to Haiti.

The first Dominican identified as indio in the Dominican Republic, but as Hispanic in the US. The next interviewee saw himself as an indio, and also as a Hispanic-American (after moving to America), yet also always Dominican. The third Dominican interviewee identified simply as indio. The fourth Dominican interviewee also identified as indio in Dominican Republic, but as Black in the US. She believed that fellow Dominicans are actually Black but will not admit it, a point of view that could be connected to her complexion (that was darker than that of the other Dominicans interviewed).

\section{Discussion}

With about $40 \%$ of US Hispanics born outside the mainland US (Roth 2012), it is important to understand facets of their identity that provide insight into a significant and growing segment of the US population originating in an island just over 700 miles from Miami. The Dominican interviewees communicated that they view Haitians as a people with whom they have nothing in common. Consistent with historical precedent, they saw Haitians as an underclass relegated to arduous work; during World War I, when the European sugar supply was cut off, Americans occupied the Dominican Republic (1916-1924) and imported Haitian workers to fill undesirable jobs that Dominicans turned down. The association of Haitians with low status work remains unchanged (Whitten and Torres 1998). This helps elevate the Dominicans, whose status is higher by comparison. Devaluing Haitians also reflects color coding wherein Haitians' darker, more homogenous hue is linked to lower social standing (Sagás 2000), while whiteness provides symbolic capital. By having an underclass of dark-skinned people, the Dominicans can place themselves in the middle class as indio, with the whitest blancos as the racial elite, and dark-skinned Black people as the lowest caste.

In order to associate themselves more closely with White people, the relativity of racial schemas make Haitians functional given that a dark-skinned person would call someone with lighter skin "blanco" while a lighter-skinned person might call that same person trigueño (wheat colored). Similarly, within a family, the lightest or darkest might be identified as "la blanquita" or "el negrito" because of relative comparisons (Roth 2012). As a result, incorporation of Haitians within the Dominican racial consciousness makes them relatively lighter which confers higher social status. In accordance with this racial schema, blackness is externalized so that Haitians serve as the bottom rung of the social ladder, making success relative to those darker and poorer. Consistent with this type of relational self-assessment, Dominicans of a higher social class are less apt to reject a Black identity in the absence of a need to define their success in relation to those lower in the social hierarchy (Roth 2013).

Our finding is that Haitians see common cultural ground, such as food and a love of dancing, while Dominicans focus on differences, such as language, which is consistent with a study of second generation Dominican high school students in Providence, Rhode Island for whom speaking Spanish demonstrates a "non-Black identity" in favor of an ethnolinguistic identity. This language-based sense of self appears to supersede the role of skin color (phenotype), religion, or music (e.g., bachata, salsa, merengue, and reggaeton) in identity (Bailey 2001; Cherry 2015). Interestingly, language can also 
legitimize Whites' marginalization of Dominicans in the US, given the stigmatization of speaking Spanish as backward (Rosa 2016).

As Dominican immigrants experience acculturation, they undergo a type of cognitive rewiring where concepts of race shift based on new information gained through social networks, institutions, and the media that are influenced by trends in immigration, transnationalism, and globalization (Roth 2012). Despite the variety of factors involved in this "rewiring", lighter-skinned individuals maintain an advantage not dissimilar to that conferred by career success (power and money). This phenomenon extends to African Americans who are called (and considered) White by both their peers and by White people based on factors such as their educational accomplishments, career success, financial status, and neighborhood-attributes that override their Black phenotype, and are independent of their own self-perception (Carbado and Gulati 2013; Thelamour and Johnson 2016).

While many Dominicans maintain an indio identity rooted in sociocultural factors and not just skin color, African American identity relies more on the validation of Blackness over cultural attributes (partly lost as a result of slavery). Zoe Saldana, a light-skinned Puerto Rican and Dominican actress (with some Haitian heritage), spurred controversy in 2016 when she was cast as musician Nina Simone, a dark-skinned African American. While Dominicans embrace and admire those with lighter skin, some African Americans believe that Saldana should have turned down the role to allow a darker-skinned actress to portray Simone. Some African Americans believe that racial solidarity calls for rejecting any advantages that separate light-skinned Black people from other Black people, especially since they will still remain subordinate to Whites. Some believe that to subvert the privilege of light skin, it is necessary to dismantle the system that devalues darker-skinned Black people and rewards Black people whose phenotype and features are closer to those of white people (Oluo 2016).

Black people who immigrate to the US may feel alienated from African Americans if they are expected to place their allegiance to being Black above their culture, which for them is part of a complicated racial schema that goes far beyond phenotype. Flores-González (2017) describes a Dominican American who identifies as Latina yet is "often perceived as black because of her dark skin, [yet] does not identify racially as black and feels more distant from blacks than any other racial group" (p. 87, emphasis added).

Afrolatinos realize their status in the US hierarchy is below white people, but yet at the same time, may lack solidarity with African Americans especially in regard to docility encouraged in an exploitative service sector economy (Ramos-Zayas 2011). This trait, also known as "buena presencia" or non-aggressiveness, has been identified as helping to create a tractable labor force (Honig 2001). As "super citizen migrants", Afrolatino immigrants hold out hope for the American Dream and contrast with other minorities lacking the same mindset. Rewarding immigrants' docility and acceptance of white hegemony furthers white interests while pitting Black immigrants against African Americans who fight for change. Meanwhile, the immigrants can gain cultural capital by distancing themselves from African American efforts to challenge the status quo (Jackson 2010).

Similarly, African Americans, like Haitians, are more apt to consider their struggles for empowerment and against subjugation by White people as a central part of their identity. Because of Dominicans' history of embracing the white part of their heritage, they may be less prone to seeing the US White establishment as oppressors undeserving of prima facie respect, and instead view resentment of White people in power as psychological weakness. In fact, some deem resentment a cause, not a consequence, of racism. Their different perspective based on Dominican culture and greater acceptance of the power structure makes them more appealing to Whites, which results in a higher position in the hierarchy of Black people living in the US (Ramos-Zayas 2011).

These factors likely contribute to the fact that only $18 \%$ of US Afrolatinos identify one of their races as Black, less than half as many as those who identify as White (or partly White) (López and Gonzalez-Barrera 2016). Beginning with the 1980 US Census, Hispanic has been considered an ethnicity but not a race (Gonzalez-Barrera and López 2015; Humes et al. 2010). Revisions planned for the next decennial data collection (in 2020) include a reversal in which Hispanic ethnicity would no longer 
be assessed as a separate question, but rather would be incorporated into a single question about racial identity.

The proposed re-design for the 2020 Census has the potential to reduce the relatively high proportion of Hispanics that either skip the Census race question or select "some other race", an overly broad, less useful category (Compton et al. 2010). Subsuming Hispanic ethnicity into a question about race would allow respondents to select all applicable racial and ethnic options (Krogstad and Cohn 2014; Compton et al. 2010). However, parallel with examples of the different categories, such as "German, Irish, Lebanese, Egyptian" for Whites, the examples proposed to illustrate who is Black are "Haitian and Nigerian". Although some Afrolatinos already do not identify as Black, using "Haitian" as an example of the Black racial group could lead to even fewer Afrolatino Dominicans identifying as Black due to antihaitianismo.

\section{Limitations}

Because the interviewer was Dominican, respondents who were Dominican may have been more comfortable expressing negative views of Haitians. In Roth's research about Hispanic identity (2012), she noted that a variety of stimuli trigger the racial schema evoked; in this research, relevant factors include the author's status as an American doing the interview, the interview setting, the nature of the conversation and how questions were posed, as well as the fact that some of the words in Spanish lacked an exact translation in English.

Racial identity is complex and mutable and therefore requires more analysis and data that confirm our findings as well as address how Dominicans would respond to having Haitians mentioned as an example of Black race in census data. A larger sample from various US geographical locations is also needed in order to have a more complete picture of the relationship between Dominicans and Haitians in the US.

\section{Conclusions}

The lines of a racial in-group depend on cultural traits ascribed symbolic meaning such as spoken language, food, art, religion, and music that exist within the confines demarcated by the "other". The formation of group consciousness stems from microcosmic childhood learning evidenced in our interview data revealing previously unreported elements underlying Dominican antipathy towards Haitians including the depiction of Haitians as threatening-capable of casting spells and acting as agents of punishment for misbehaving Dominican children-negative portrayals not matched by Haitians' views of Dominicans.

In addition to these elements of individuals' socialization, macrocosmic influences like colorism play an equally important role. These forces may operate on a governmental level, specifically the promotion of antihaitianismo and acute awareness of skin color that prizes whiteness associated with Europeans over blackness associated with Haitians. These various factors coalesce and elevate Dominicans, setting them apart from Haitians, as reflected in Dominican Independence Day that celebrates the end of Haitian occupation rather than the end of Spanish rule.

Dominican identity seems to be distinct from African American identity, even though the hue of many African Americans resembles that of Dominicans who call themselves indio. The divide between Dominicans and African Americans seems to have more to do with contrasts in interactional style and political acquiescence, differences that fade in subsequent generations. In contrast, the divide between Dominicans and Haitians is longstanding and deep, complicating the achievement of cultural rapprochement.

Race is a negotiated, constructed status, determined by perceptions of others and dynamic individual self-identification. Haitians, as outsiders, serve to enclose the boundaries of Dominican self-identification, a phenomenon reinforced by fluid and interactional historical, economic, and political dividing lines. These phenomena reflect the complexity of race and how its assessment should 
occur within a relational context that recognizes historical conflicts, childhood socialization, as well as psychosocial and geopolitical facets of racial identity, without diminishing efforts to dispel racial bias.

Author Contributions: Valerie Lamb collected the data. Valerie Lamb and Lauren Dundes contributed equally in writing the paper.

Conflicts of Interest: The authors declare no conflict of interest.

\section{References}

Ahmed, Azam. 2016. Hurricane Matthew Makes Old Problems Worse for Haitians. New York Times. October 6. Available online: http:/ /www.nytimes.com/2016/10/07/world/americas/hurricane-matthew-haiti.html? _r $=0$ (accessed on 15 December 2016).

Amnesty International. 2016. Haiti/Dominican Republic: Reckless Deportations Leaving Thousands in Limbo. June 15. Available online: https:/ /www.amnesty.org/en/latest/news/2016/06/haiti-dominican-republicreckless-deportations-leaving-thousands-in-limbo/ (accessed on 15 December 2016).

Appiah, Kwame Anthony. 2015. Race in the Modern World: Problem of the Color Line. Foreign Affairs 94: 1-8.

Bailey, Benjamin. 2001. Dominican-American Ethnic/Racial Identities and United States Social Categories. International Migration Review 35: 677-708. [CrossRef]

Barth, Fredrik. 1969. Ethnic Groups and Boundaries. In The Social Organization of Culture Difference. Boston: Little Brown.

Brown, Anna, and Eileen Patten. 2013. Hispanics of Dominican Origin in the United States. Available online: http: / /www.pewhispanic.org/2013/06/19/hispanics-of-dominican-origin-in-the-united-states-2011/ (accessed on 20 December 2016).

Buchanan, Angela B., Nora G. Albert, and Daniel Beaulieu. 2010. The Population with Haitian Ancestry in the United States. Available online: https://www.census.gov/prod/2010pubs/acsbr09-18.pdf (accessed on 15 January 2017).

Candelario, Ginetta E. B. 2007. Black behind the Ears: Dominican Racial Identity from Museums to Beauty Shops. Durham: Duke University Press.

Carbado, Devon W., and Mitu Gulati. 2013. Acting White? New York: Oxford University Press.

Cherry, Arvenita Washington. 2015. Spaces of Possibilities: Using Diaspora as a Tool to Unravel Complex Ideological Frameworks That Impact Diasporic Encounters among African Americans, Afro-Latinas/os, and Latina/os of African Descent in a Prince George's County, Maryland Public Middle School. Transforming Anthropology 23: 28-41.

Compton, Elizabeth, Michael Bentley, Sharon Ennis, and Sonya Rastogi. 2010. Census Race and Hispanic Origin Alternative Questionnaire Experiment. Available online: https://www.census.gov/2010census/pdf/2010_ Census_Race_HO_AQE.pdf (accessed on 10 March 2017).

Duaney, Jorge. 2011. Los Países: Transnational migration from the Dominican Republic. In Blurred Borders: Transnational Migration between the Hispanic Caribbean and the United States. Chapel Hill: The University of North Carolina Press, pp. 169-86.

Dubois, Laurent. 2013. Haiti: The Aftershocks of History. London: Picador.

Eller, Anne. 2016. We Dream Together: Dominican Independence, Haiti, and the Fight for Caribbean Freedom. Durham: Duke University Press.

Eller, Anne. 2017. Race Records. NACLA Report on the Americas 49: 90-94. [CrossRef]

Epsy, Jay. 2015. Dominican, Black, and Afro-Latino: A Confession/Dominicano, Negro, y Afro-Latino. La Galería Magazine. April 10. Available online: http://www.lagaleriamag.com/dominican-black-andafro-latino-a-confessiondominicano-negro-y-afro-latino-una-confesion/ (accessed on 12 March 2017).

Flores-González, Nilda. 2017. Citizens but Not Americans: Race and Belonging among Latino Millennials. New York: NYU Press.

Garzaniti, Ivana, Glenn Pearce, and John Stanton. 2011. Building Friendships and Relationships: The Role of Conversation in Hairdressing Service Encounters. Managing Service Quality: An International Journal 21: 667-87. [CrossRef]

Gates, Henry Louis. 2011. Black in Latin America. New York: NYU Press. 
Gonzalez-Barrera, Ana, and Mark Hugo López. 2015. Is Being Hispanic a Matter of Race, Ethnicity or Both? Pew Research Center. June 15. Available online: http:/ / www.pewresearch.org/fact-tank/2015/06/15/isbeing-hispanic-a-matter-of-race-ethnicity-or-both/ (accessed on 15 February 2017).

Guzmán, Daysi Josefina. 1974. Raza y lenguaje en el Cibao. Eme Erna. Estudior Dominicanos 2: 3-45.

Hebblethwaite, Benjamin. 2015. The scapegoating of Haitian Vodou Religion: David Brooks's (2010) Claim that "Voodoo" is a "Progress-Resistant" Cultural Influence". Journal of Black Studies 46: 3-22. [CrossRef]

Honig, Bonnie. 2001. Democracy and the Foreigner. Princeton: Princeton University Press.

Howard, David. 2001. Coloring the Nation: Race and Ethnicity in the Dominican Republic. Boulder: Lynne Reinner Publishers.

Humes, Karen R., Nicholas A. Jones, and Roberto R. Ramirez. 2010. Overview of Race and Hispanic Origin: 2010. Available online: https://www.census.gov/prod/cen2010/briefs/c2010br-02.pdf (accessed on 15 February 2017).

Jackson, Regine O. 2010. Black Immigrants and the Rhetoric of Social Distancing. Sociology Compass 4: 193-206. [CrossRef]

Jha, Meeta. 2016. The Global Beauty Industry: Colorism, Racism, and the National Body. New York: Routledge.

Johnson, Violet Showers. 2016. When Blackness stings: African and Afro-Caribbean Immigrants, Race, and Racism in Late Twentieth-Century America. Journal of American Ethnic History 36: 31-62. [CrossRef]

Krogstad, Jens Manuel, and D’Vera Cohn. 2014. U.S. Census Looking at Big Changes in How It Asks about Race and Ethnicity. Pew Research Center. March 14. Available online: http:/ /www.pewresearch.org/fact-tank/ 2014/03/14/u-s-census-looking-at-big-changes-in-how-it-asks-about-race-and-ethnicity/ (accessed on 12 February 2017).

Krohn-Hansen, Christian. 2001. A Tomb for Columbus in Santo Domingo. Political Cosmology, Population and Racial Frontiers. Social Anthropology 9: 165-92. [CrossRef]

Lennox, Corinne, and Carlos Minott. 2011. Inclusion of Afro-Descendants in Ethnic Data Collection: Towards Visibility. International Journal on Minority and Group Rights 18: 257-75. [CrossRef]

López, Gustavo. 2015. Hispanics of Dominican Origin in the United States, 2013. Available online: http: / /www.pewhispanic.org/2015/09/15/hispanics-of-dominican-origin-in-the-united-states-2013/ (accessed on 25 March 2017).

López, Gustavo, and Ana Gonzalez-Barrera. 2016. Afro-Latino: A Deeply Rooted Identity among U.S. Hispanics. March 1. Available online: http:/ / www.pewresearch.org/fact-tank/2016/03/01/afro-latino-a-deeplyrooted-identity-among-u-s-hispanics / (accessed on 25 March 2017).

Mayes, April J. 2014. The Mulatto Republic: Class, Race, and Dominican National Identity. Gainesville: University Press of Florida.

Negrón, Rosalyn. 2014. Diversity, Multiethnicity, and Latino Social Networks. Societies 4: 222-39. [CrossRef]

Oliver, José R. 2009. Caciques and Cemi Idols: The Web Spun by Taino Rulers between Hispaniola and Puerto Rico. Tuscaloosa: University of Alabama Press.

Oluo, Ijeoma. 2016. Nina Simone, Zoe Saldana, and Light-Skinned Fragility. The Establishment. March 3. Available online: http://www.theestablishment.co/2016/03/03/nina-simone-zoe-saldana-and-lightskinned-fragility/ (accessed on 16 April 2017).

Patten, Eileen. 2015. Who Is Multiracial? Depends on How You Ask: A Comparison of Six Survey Methods to Capture Racial Identity. Washington: Pew Research Center. Available online: http:/ /www.pewsocialtrends.org/2015/ 11/06/who-is-multiracial-depends-on-how-you-ask/ (accessed on 15 January 2017).

Paulino, Edward. 2016. Dividing Hispaniola: The Dominican Republic's Border Campaign against Haiti, 1930-1961. Pittsburgh: University of Pittsburgh Press.

Ramos-Zayas, Ana Y. 2011. Learning, Affect, Embodying Race: Youth, Blackness, and Neoliberal Emotions in Latino Newark. Transforming Anthropology 19: 86-104. [CrossRef]

Rosa, Jonathan Daniel. 2016. Standardization, Racialization, Languagelessness: Raciolinguistic Ideologies across Communicative Contexts. Journal of Linguistic Anthropology 26: 162-83. [CrossRef]

Roth, Wendy D. 2012. Race Migrations: Latinos and the Cultural Transformation of Race. Stanford: Stanford University Press.

Roth, Wendy D. 2013. A Single Shade of 'Negro': Henry Louis Gates' Depiction of Blackness in the Dominican Republic. Latin American \& Caribbean Ethnic Studies 8: 92-96.

Sagás, Ernesto. 2000. Race and Politics in the Dominican Republic. Gainesville: University Press of Florida. 
Simmons, Kimberly Eison. 2008. Navigating the Racial Terrain: Blackness and Mixedness in the Untied States and the Dominican Republic. International Migration Review 16: 95-111. [CrossRef]

Simms, Tanya M., Carol E. Rodríguez, Rosa Rodríguez, and René J. Herrera. 2010. The genetic structure of populations from Haiti and Jamaica reflect divergent demographic histories. American Journal of Physical Anthropology 142: 49-66. [CrossRef] [PubMed]

Suriel, Jo-Anne. 2005. The Myth of the Indio: Race and the Dominican Performance of Identity. Praxis 17: 21-34.

Telles, Edward, Rene D. Flores, and Fernando Urrea-Giraldo. 2015. Pigmentocracies: Educational Inequality, Skin Color and Census Ethnoracial Identification in Eight Latin American Countries. Research in Social Stratification and Mobility 40: 39-58. [CrossRef]

Thelamour, Barbara, and Deborah J. Johnson. 2016. Exploring Black Immigrants' and Nonimmigrants' Understanding of "Acting Black" and "Acting White". Journal of Black Psychology 43: 1-25.

Torres-Saillant, Silvio. 2000. The Tribulations of Blackness: Stages in Dominican Racial Identity. Dominican Republic Literature and Culture 23: 1086-11. [CrossRef]

Tuider, Katherine, and Evan Caplan. 2012. Dominican Republic (Other Places Travel Guide). n.p.: Other Places Publishing.

Whitten, Norman, and Arlene Torres. 1998. To Forge the Future in the Fires of the Past. In Blackness in Latin America and the Caribbean: Social Dynamics and Cultural Transformations. Bloomington: Indiana University Press, pp. 3-33.

World Factbook. 2016a. CIA. Dominican Republic. Available online: https://www.cia.gov/library/publications / the-world-factbook/geos/dr.html (accessed on 15 October 2016).

World Factbook. 2016b. CIA. Haiti. Available online: https://www.cia.gov/library/publications/the-worldfactbook/geos/ha.html (accessed on 15 October 2016).

Wucker, Michele. 1999. Why the Cock Fights: Dominicans, Haitians and the Struggle for Hispaniola. New York: Hill \& Wang.

(C) 2017 by the authors. Licensee MDPI, Basel, Switzerland. This article is an open access article distributed under the terms and conditions of the Creative Commons Attribution (CC BY) license (http://creativecommons.org/licenses/by/4.0/). 